include size and ability to root at the nodes) between these sub-spocios. The only chromosome numbers regularly found are $2 n=56$ and $2 n=64$, though some populations have, in addition, $B$-chromosomes. In Continental Europe, a diploid with $2 n=14$ is known from one locality, and tetraploids $(2 n=28$ and $2 n=32)$ also occur. Thero are thus, apparently, two basic numbers to the polyploid sories. The tetraploids examined always show bivalent pairing, but the octoploids have some quadrivalents as woll as univalents. In the extensive collections studied, all the plants were self-incompatible and hence outbreeding, and the wild populations were all somewhat polymorphic. There appeared to be little morphological difference between members of the same sub-species with different chromosome numbers. Plants at the same chromosome-level were all interfertile, but there was some drop in fertility in crosses betweon plants with 56 and 64 chromosomes. Information was also presented about tho frequency of $B$-ehromosomes in natural populations and their mode of inheritance.

In the general discussion opened by Prof. Valentine, the phytogeographical questions raised by some of the papers were pointed out. Thus, the distributions of the Dryas spp., the Quercus spp., and the Chrysanthemum and Tripleurospermum cytodemes, all posed probloms about the conditions in the past under which speciation had occurred, and the subsequent conditions in which allopatric populations had become sympatric to varying extents. Dr. D. M. Moore mentioned the South American species of Caltha which, unlike $C$. palustris, were selfcompatible, and suggested that this might be an examplo of Baker's law concerning the breeding system of successful long-distance migrants.
D. H. VALENTINE

\title{
ROCK AND MINERAL COLLECTING IN CANADA
}

$I^{\mathrm{T}}$ $\mathbf{T}$ is surely an innovation, a most welcome one, to find an official Geological Survey publication devoted entirely to the needs of the enthusiastic amateur or professional geologist bent on collection of fine mineral and type-rock specimens. But this has in fact been surprisingly and most efficiently achieved in three small com. panion volumes by Ann P. Sabina recently published by the Geological Survey of Canada*. These make most instructive and, if not to other countries, provocative reading - provocative in the sense that one could wish that the example could be emulated elsewhere on the same scale. To traverse the length and breadth of this farflung Dominion with the sole object of guiding people exactly where and how to travel to discover the best specimens of minerals, in many cases obviously museum pieces, also of well-known or more exotic rock-types; to give them maps, precise site-locations, itineraries, descriptions of the 'finds' to be obtained; information on where to look for the best material, how to collect, the working tools to use, even appropriate clothing to wear, also how to preserve and record what has been collected: all this within three small pocket-size booklots, easily readable by virtue of the non-technical style adopted, is a great achievement indeod.

The plan of each of these guides is straightforward and orderly. Volume 1 covers Yukon, North-west Territories, and the Provinces of British Columbia, Alberta, Saskatchewan and Manitoba. Volume 2 is concerned with Ontario and Quebec (this is the largest of the three). Volume 3 covers New Brunswick, Nova Scotia, Prince Edward Jsland and Newfoundland. The common scheme in every case is to list the chief mineral and rock collecting areas in each Province, include a small-scale map showing the locations of these areas, and follow by a detailed description of each area headed by the mineral or rock titles to be anticipated in each area. In many cases small location maps, but on a sufficiontly large scale, are inset for these areas so that no difficulty can possibly arise from inability to locate the site. Each book is enriched with some beautiful photographic reproductions of museum type specimens collected from localities described in the text.

These records of Canadian mineral occurrences are not, only impressive but also must inevitably whet the inborm collector's appetite wherever he may be. The search is, as customarily everywhere, in mines (tip-heaps never to be neglected however ancient), natural outcrops (including alluvial gravels and beach deposits in specific areas) and

* Rock and Mineral Collecting in Cunada. By Ann P. Sabina. Vol. 1 Yukon, Northwest Territories, British Columbia, Alberta Saskatchewan and Manitoba; pp. iv $+147 ; 1.30$ dollars. Vol. 2 . Ontario and Quebec; pp. iv + $252 ; 1.65$ dollars. Vol. 3. New Brunswick, Noma Scotia, Prince Edward Island, Miscellancous Report 8, Ottawa; 1964). quarries. Some tempting records of fine mineral specimens taken at random from these pages may be quoted: in Yukon Territory (Kluane Lake-Whitehorse Area), black olivine crystals often more than $3 \mathrm{in}$. in length; in Northwest Territories (Macbeth Fiord Area, Baffin Island), tourmaline crystals up to $3 \mathrm{ft}$. long and 6 in. across in pegmatite dykes; in Amadjuak Bay-Lake Harbour Area, Baffin Island, white scapolite crystals 5 in. in diameter in crystalline limestone; in Great Slave Lake Area, blue cordierite prismatic crystals up to 4 in. $\times 2$ in.; in British Columbia (Hazelton Area), scheelite crystals up to 2 in. in diameter; in Vernon Area, thick crystals of staurolite up to $3 \mathrm{in}$. long and associated kyanite crystals more than 2 in. long; in Saskatchewan (Mackintosh Bay), red garnets up to $2 \mathrm{in}$. across in biotite schist, and in the Cypress Hills Area, selenite crystals up to 5 in. long; in Manitoba (Winnipeg River Area), green beryl crystals from 0.5 in. to 12 in. across. In Ontario (Sudbury Area), blue and green bladed kyanite up to 4 in. long; in Wilberforce Area, hornblende and apatite crystals up to 6 in. across, also uraninite in 0.75 in. crystals; in Baneroft Area, black mica in 'books' up to $2 \mathrm{ft}$. in diameter; in Quebec (PreissacLacorne Area), spodumene crystals up to $4 \mathrm{ft}$. long; similar impressive mineral finds are chronicled from New Brunswick, Nova Scotia, Prince Edward Island and Newfoundland. Descriptions of localities of many wellknown igneous rock-types of special interest to the petrologist are to be found throughout these books.

Some other interesting features are to be noted from these guides. The Geological Survey of Canada makes available to mineralogists, students and others authenticated sets of specimens to aid identification and recognition of rocks and minerals; one set comprises 35 common mincrals, another 35 rock chips, and a third, 120 specimens representing the raw materials of Canada's mineral industry. The names and addresses of amateur mineral and rock clubs, of which no less than fifty-five are spread over the Dominion, are listed; appendixes include lists of books on mineralogy in general, on minerals and rocks for the amateur, on gemmology, and on the lapidary's art.

There is room for a similar official publication in the United Kingdom. It would in no sense transgress the existing periodic geological and mineralogical publications of national and local societies, or of the Geological Survey as such, wherein much comparable information at present lies buried. Its advent would do much to stimulate public interest in geology and mineralogy, and would certainly be a boon to schoolteachers in their task of presenting these subjects to beginners both in the classroom and in the field. A similar idea for guidance in fossil collecting is by no means excluded from such consideration, surely an equally popular hobby with many amateur geologists? 